\title{
CHALLENGING AND SUCCESSFUL CONDUCT IN DENTOALVEOLAR TRAUMA: CASE REPORT
}

\section{CONDUTA DESAFIADORA E BEM-SUCEDIDA EM TRAUMA DENTOALVEOLAR: RELATO DE CASO}

\author{
Matheus Gonçalves Ferreira Leal ${ }^{1 *}$ (D), Maiara Lopes Ferreira da Silva ${ }^{2}$ (D), Lorran de Andrade \\ Pereira $^{3}$ (D), Elias Almeida dos Santos ${ }^{3}$ (D), Henry Mcarter Senra Almeida ${ }^{4}$, Antônio Lucindo Pinto \\ de Campos Sobrinho ${ }^{5}$ (D)
}

${ }^{1}$ Escola Bahiana de Medicina e Saúde Pública, Salvador, BA, Brasil

${ }^{2}$ Universidade Tiradentes, Aracaju, SE, Brasil.

${ }^{3}$ Universidade Federal da Bahia, Salvador, BA, Brasil

${ }^{4}$ Faculdade Adventista da Bahia, Cachoeira, Bahia, Brasil

${ }^{5}$ Hospital Geral do Estado da Bahia, Salvador, Bahia, Brasil.

*matheusgoncalvesfl@gmail.com

\section{ABSTRACT}

The dentoalveolar trauma it is a frequent adversity to the heathy system, and it needs an early diagnosis and intervention. The severity of those lesions can diversify according to its classification, that goes from a simple enamel crack to dental avulsion and bone fractures. Therefore, the aim of the study is to report a clinical case of dentoalveolar trauma associated the fracture of the anterior bone block of the maxilla that was belatedly treated through bidigital reduction and splinting. Male patient, car accident victim, attended the emergency service four days after the trauma. During the maxillofacial physical exam, it was possible to observe mobility of the anterior maxillary block and lateral dislocation of the anterior teeth. On face tomography it was possible to analyze the presence of a fracture line at the vestibular board and palatine of the anterior region of the maxilla, as a lateral dislocation of the 12,11, 21 e 22 units. Despite the long waiting period post trauma, the proposed treatment was a closed reduction, associated to semi-rigid containment, offering stability to the fractured segment and favorable conditions to the correct bone cicatrization. The initial management of dental trauma has a great influence on the prognosis; however, it was possible to observe through this case that the late treatment presents satisfactory results, helping to reestablish the patient's function and aesthetics in a less invasive way.

Keywordls: Bone Fractures. Dental Trauma. Facial Trauma.

\section{RESUMO}

O trauma dentoalveolar é uma adversidade frequente para o sistema de saúde e necessita de diagnóstico e intervenção precoce. A gravidade dessas lesões pode variar de acordo com a sua classificação, de simples trincas em esmalte a avulsões do órgão dental e fraturas ósseas. Sendo assim, o objetivo deste trabalho é relatar um caso clínico de trauma dentoalveolar associado a fratura do bloco ósseo em região anterior de maxila, tratado tardiamente por meio de redução bidigital e esplintagem. Paciente do sexo masculino, vítima de acidente automobilístico, compareceu ao serviço de emergência 04 dias após o trauma. Durante o exame físico maxilofacial foi possível observar presença de mobilidade em bloco anterior de maxila e luxação lateral dos dentes anteriores. Na tomografia de face foi possível analisar a presença de linha de fratura em tábua vestibular e palatina da região anterior da maxila, assim como luxação lateral envolvendo as unidades 12,11 , 21 e 22. Apesar do longo período pós-trauma, o tratamento proposto foi a redução fechada, associada a instalação de contenção semirrígida, proporcionando estabilidade ao segmento fraturado e ambiente propício para correta cicatrização óssea. O manejo inicial do trauma dental tem grande influência no prognostico, no entanto, foi possível observar por meio desse caso, que o tratamento tardio apresenta resultados satisfatórios, auxiliando no reestabelecimento da função e estética do paciente de forma menos invasiva.

Palavras-chave: Fraturas Ósseas. Traumatismos Dentários. Traumatismos Faciais. 


\section{INTRODUCTION}

Trauma represents considerable adversity for the unified health system, corresponding to one of the leading causes of mortality and morbidity worldwide (ZAMBONI et al., 2017). The maxillofacial region is frequently affected due to its projected anatomical position, making it susceptible to trauma that can generate aesthetic and/or functional damage (PATIL et al., 2016). The main etiological factors include: traffic accidents, physical aggression, falls, sports, and work accidents (ZAMBONI et al. 2017).

Maxillofacial trauma is associated with about $15 \%$ of hospital emergencies. Among these, $2 \%$ are isolated dentoalveolar lesions, affecting mainly male children and young adults (FONSECA et al., 2014). This type of injury can range from simple cracks in tooth enamel to avulsion of the tooth unit; still, occurring in isolation or associated with alveolar bone fractures of the maxilla and/or mandible (KALLEL et al., 2020).

According to the literature, the specialized care search should be carried out immediately once the treatment success is directly related to the short post-trauma period (KALLEL et al., 2020). The diagnosis must be established through the signs and symptoms presented, pulp vitality test, associated with imaging exams that show fundamental and determinant information for the treatment (ALIMOHAMMADI, 2017).

In alveolar fractures, the buccal and lingual/palatal bone plate are affected. Therefore, it is possible to clinically observe atypical mobility during manipulation, as well as associated tooth displacement, occlusal dystopia, and soft tissue injuries (BOURGUIGNON et al., 2020). Periapical radiography, used in an outpatient setting, provides essential information about the location and extent of the fracture, aiding in the diagnosis and subsequent control (HUPP et al., 2015).

However, in a hospital environment, periapical radiography is not used due to its unavailability. Thus, it is necessary to use conventional medical radiographs of the face or, preferably, multislice computed face tomography. This last one, considered the gold standard in trauma centers since it provides greater precision and provides details of the location, extension of the lesion, and involved bone tables, without the presence of overlapping seen on two-dimensional radiographs (FONSECA et al., 2014).

Dentoalveolar fractures treatment is established according to their classification. The intervention can be performed closed or open, depending on the severity of the injury. The literature recommends bidigital reduction associated with early stabilization of fractured segments using steel wires and composite resin (PATIL et al., 2014).

Therefore, the aim of this paper is to report a clinical case of dentoalveolar trauma in the anterior maxilla, confirming the long-term effectiveness of late conservative treatment.

\section{CASE REPORT}

A 24-year-old male patient, a victim of a motorcycle accident, was treated at the Maxillofacial Surgery and Traumatology Service (MSTS) of the General Hospital of the State of Bahia (GEH-BA), 04 (four) days after the trauma. He evolved lucid and oriented in time and space, cooperative and good general condition, Glasgow 15, without signs and/or symptoms suggestive of Cranioencephalic Trauma.

Maxillofacial physical examination revealed mobility of the maxilla upon manipulation, limitation of mouth opening, occlusal dystopia, difficulty in phonation, lacerations and contusion in the oral mucosa and gums, lateral luxation in teeth 11, 12, 21, and 22, and orthodontic appliance in both arches (Figure 1).

After anamnesis and clinical examination, local anesthesia was performed with $2 \%$ lidocaine and 1: 200,000 epinephrine in the bilateral superior alveolar, bilateral infraorbital, and nasopalatine nerves. Also, removed the orthodontic appliance and bidigital reduction of the fractured dentoalveolar block (Figure 2-A), followed by splinting (semi-rigid containment) with number 0 steel wire and 
composite resin (after acid etching and application of adhesive), extending from dental units 14 to 24, for stabilization (Figure 2-B).

Figure 1 - Lateral luxation of dental units 12, 11, 21, and 22

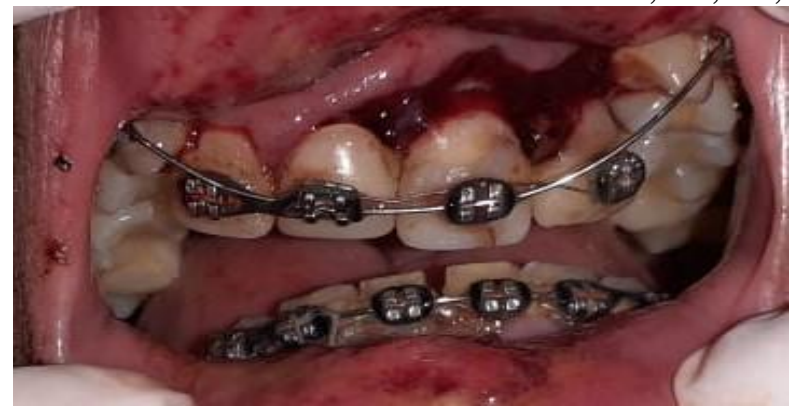

Source: the authors.

Figure 2 - A: Dentoalveolar block reduction. B: Splinting with composite resin and steel wire

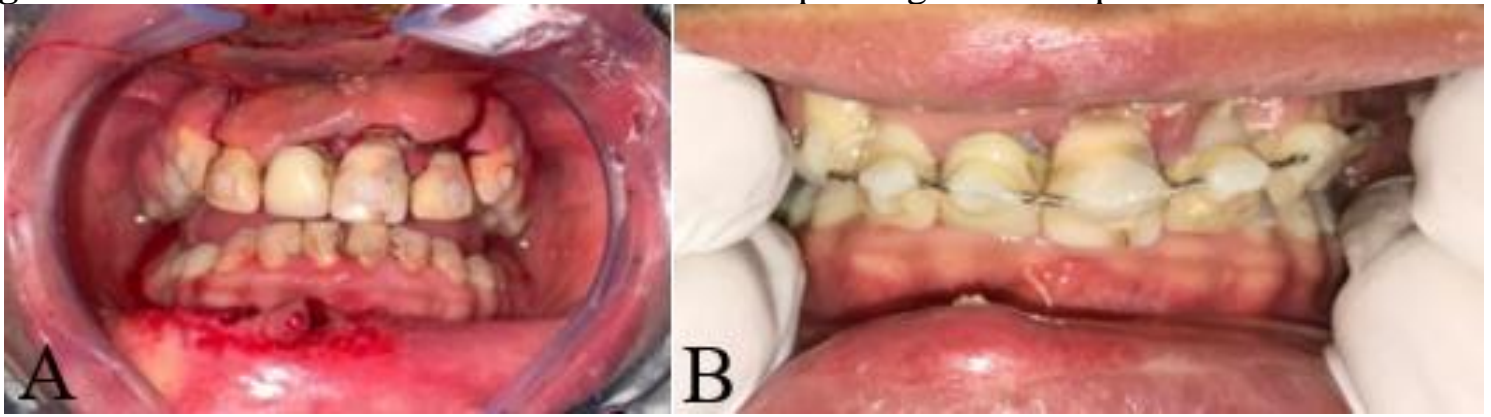

Source: the authors.

Figure 3 - Face CT after dentoalveolar trauma management
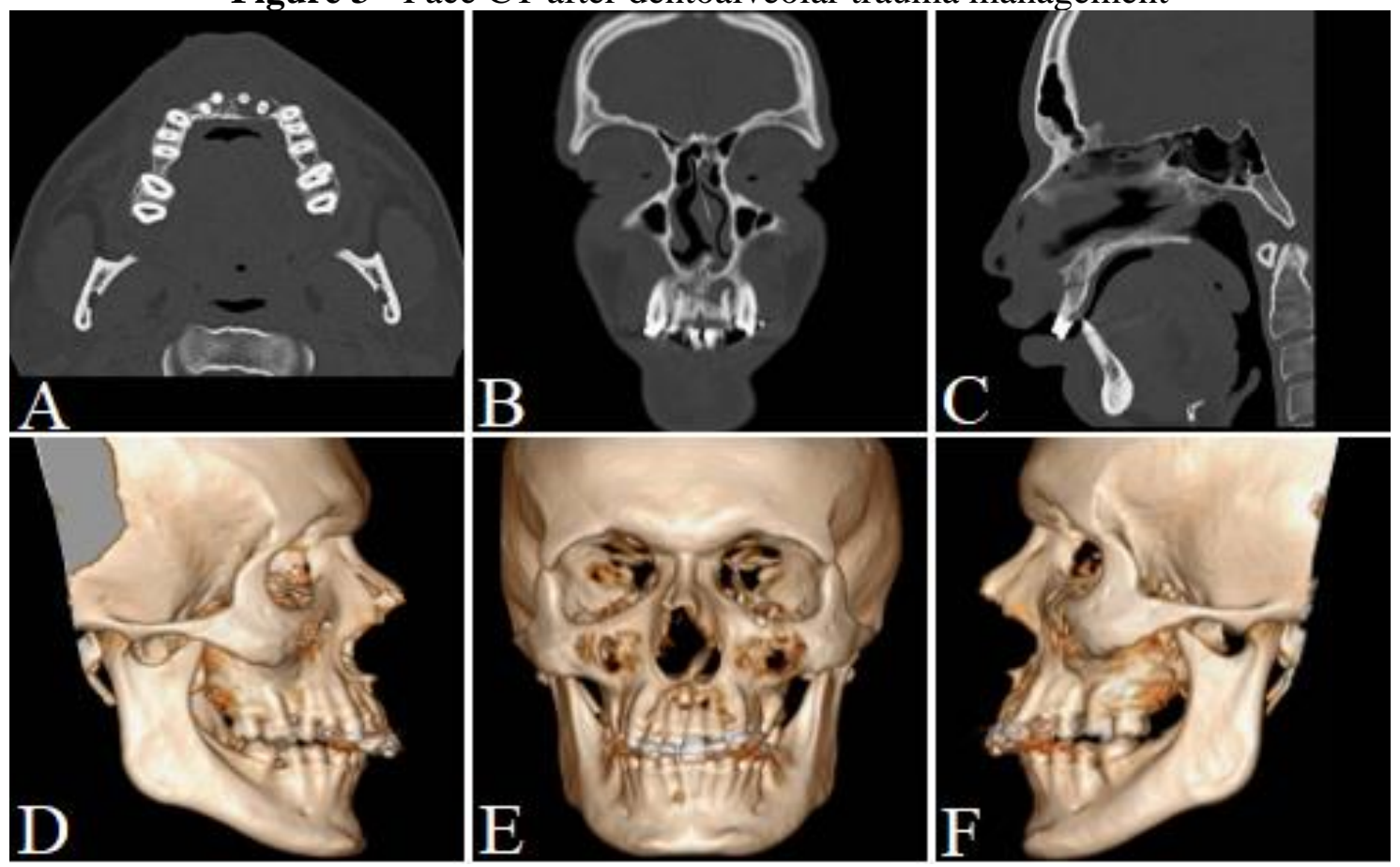

Notes: A: Axial section showing adequate repositioning of the fractured alveolar block. B: Coronal section with a hypodense image in the anterior region of the maxilla. C: Sargital cut demonstrating fracture alignment after reduction. D, E, and F: 3D reconstruction indicating satisfactory reduction and dental synthesis material in position.

Source: the authors. 
Antibiotic therapy was prescribed with Amoxicillin 500mg every 08 hours for 07 days, Nimesulide 100mg every 12 hours for 03 days, 500mg Dipyrone every 06 hours for 02 days, and $0.12 \%$ Chlorhexidine Digluconate solution to carry out mouthwash every 12 hours for 07 days. The patient was instructed about strict oral hygiene (brushing four times a day plus the mouthwash as prescribed), strictly liquid food (not chewing), and avoiding secondary trauma in the region. Moreover, the patient was referred for evaluation with an endodontist.

Twenty-one days after the procedure, the patient returned for outpatient reassessment, showing good healing, with intraoral 4-0 Vicryl sutures in position, clean and occluded, without signs of infection, dehiscence, and/or tissue necrosis. In addition, moderate dental stability was noted (Figure 4).

Figure 4 - Patient twenty-one days after the procedure performed

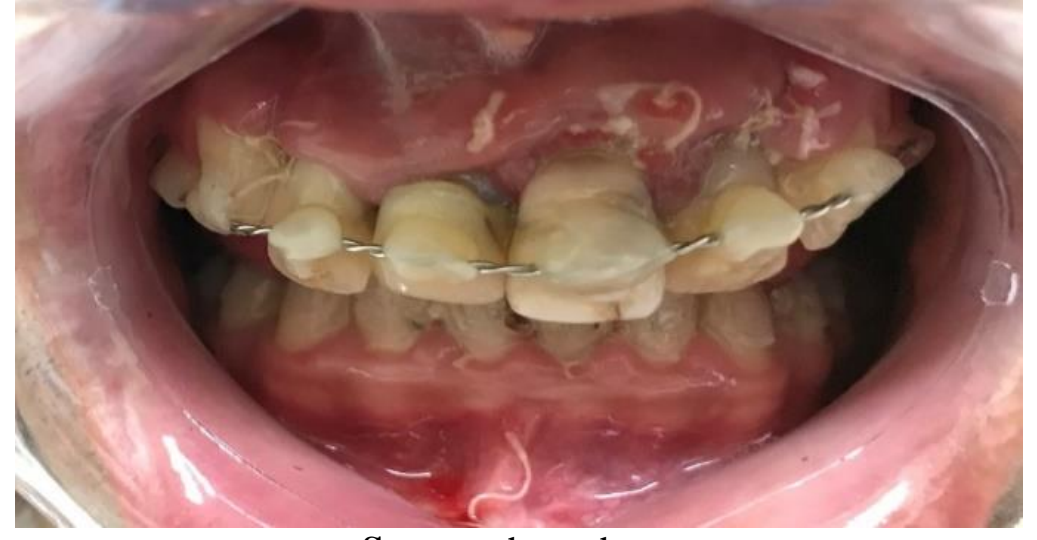

Source: the authors.

Imaging examination (panoramic and periapical radiographs of the lateral incisor and upper right canine and central incisors regions) showed an adequate reduction of the alveolar block and signs suggestive of periapical bone rarefaction in the apex region of dental units 21 and 22. Beyond that, internal root resorption was noted in dental unit 21 (Figure 5-A and B).

Figure 5 - Panoramic exam performed 21 days after the procedure (A). Periapical radiograph evidencing the radiolucent area in the apical region of units 21 and 22 and internal root resorption in unit $21(\mathrm{~B})$
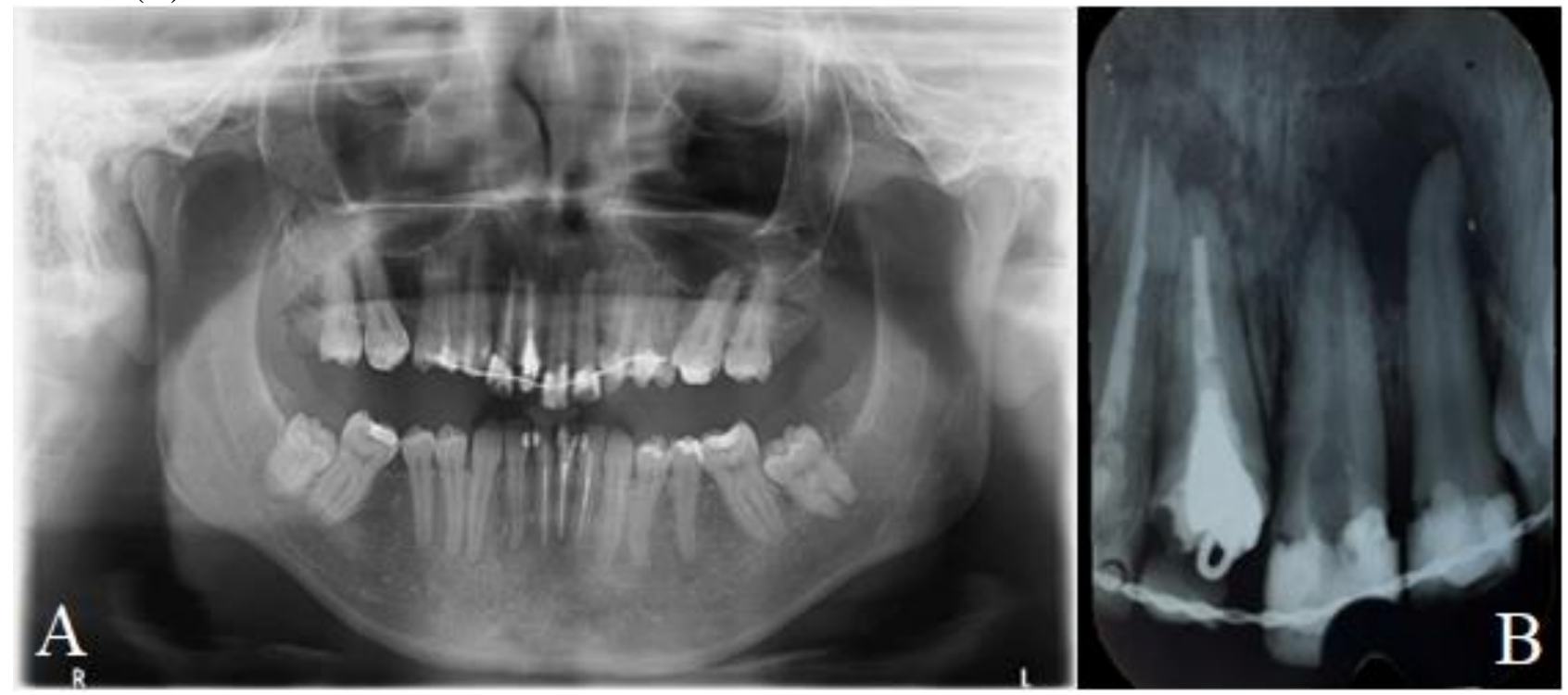

Source: the authors. 
Forty-five days after reduction and splinting, the dental synthesis material was removed and started the endodontic treatment of units 21 and 22. At the end of the treatment was noted the anterior alveolar block stability of the maxilla and absence of mobility. Three months (ninety days) after the initial procedure, in the imaging examination (panoramic and periapical radiographs of the lateral incisor and upper right canine and central incisors regions) observed suggestive signs of bone neoformation in the region of the endodontically treated dental apexes. Also, noted the consolidation of the alveolar block fracture and satisfactory repositioning of units 11, 12, 21, and 22 (Figure 6-A, $\mathrm{B}$, and $\mathrm{C})$.

Figure 6 - Panoramic radiograph 90 days after treatment, showing signs suggestive of alveolar block fracture consolidation (A). Periapical radiograph from units 11, 12, and 21, indicating bone neoformation (B). Periapical radiograph of units 21 and 22 after endodontic treatment, demonstrating bone neoformation $(\mathrm{C})$
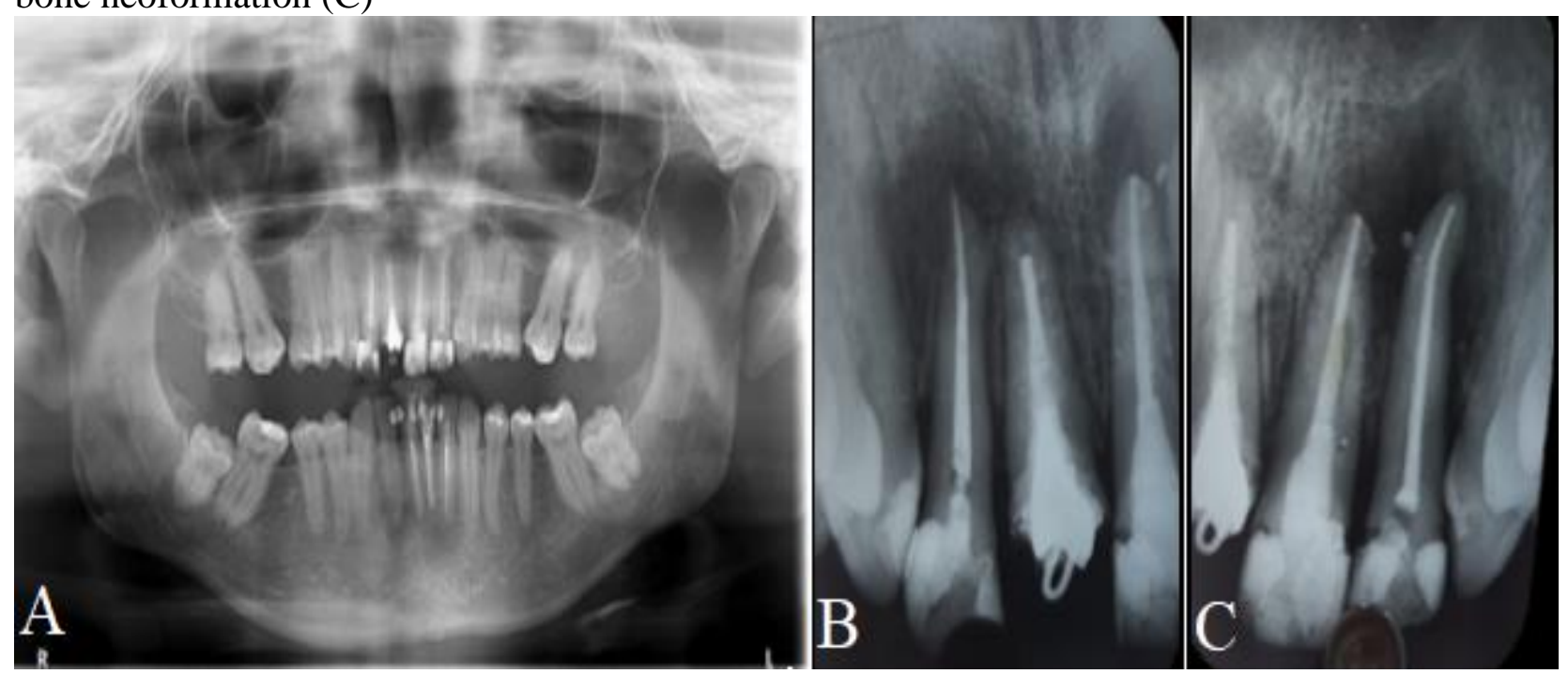

Source: the authors.

\section{DISCUSSION}

Dentoalveolar trauma happens with frequency and affects about a third of the world population (HAMMEL, 2019). Its etiology is constantly associated with impacts from traffic accidents, as in the case in question. Studies show that individuals with a maxillary protrusion, abnormal occlusion, class II-subdivision 1 dental pattern, and increased overjet (above 4mm) are more prone to dentoalveolar trauma (ALIMOHAMMADI, 2017).

Dentoalveolar lesions can affect the tooth structure in isolation or association with supporting tissues (periodontal ligament, bone, and soft tissue) (DEANGELIS et al., 2014). The classification created by Andreasen and accepted by the World Health Organization (WHO) divides fractures into dental injury, periodontal tissue, bone tissue fracture, and gum and oral mucosa injuries (FONSECA et al., 2014).

Supporting bone tissue injuries are subdivided into comminution of the alveolar bone, fracture of the alveolar process, fracture of the maxilla and mandible, and fracture of the alveolar wall, the latter is frequently related to dislocation and contusion of the gums and oral mucosa (FONSECA et al., 2014). Corroborating with the literature, this case was defined as a fracture of the alveolar wall, associated with lateral dislocation and contusion of the maxillary vestibular gingiva and upper and lower lip.

In the maxillofacial physical examination, the extra and intraoral soft tissue regions, maxillary bones, mandible, and dental arch must be accurately analyzed (MILORO et al., 2016). In addition, the airway patency must be ratified due to the risk of aspiration of bone or dental fragments, fractured 
or mobile in the oral cavity (DEANGELIS et al., 2014). Moreover, the soft tissues are thoroughly inspected, identifying the accommodation of themselves.

In these cases, it is necessary to use imaging tests that show the position and depth of the fragment. Thus, the feasibility of its removal is evaluated (CHAUHAN, 2016), and debridement and suture are performed within 24 hours due to contamination of the oral cavity (DEANGELIS et al., 2014). In the case described, the patient did not present a lack of fractured segments, eliminating the possibility of inoculation and/or aspiration of fragments.

According to Alimohammadi (2017), alveolar fractures affect several dental units and occur more frequently in the anterior region of the maxilla, displacing the fractured segment towards the palate and downwards, which corroborates the case in question, in which the units $12,11,21$, and 22 were affected in the fracture and the alveolar block was displaced posteriorly and inferiorly.

Through clinical and imaging exams, it is possible to classify the type of wound and determine the treatment. In the present report, the patient had phonetic difficulties, bone mobility to manipulation, tooth displacement, and occlusal dystopia, suggestive of fracture of the anterior maxillary block. The imaging exam (face tomography) made it possible to analyze with greater accuracy the presence of a fracture line on the buccal and palatal plate of the anterior region of the maxilla, which corroborates the area with the highest prevalence of alveolar bone fractures described in the literature.

In the presence of alveolar fracture, immobilization must be performed early through splinting (DEANGELIS et al., 2014). According to the IADT, the alveolar block must be repositioned and immobilized through a semi-rigid containment made with steel wire and composite resin, using the neighboring teeth, which have stability. The containment must remain for 4 weeks to provide an adequate initial bone healing. Also, the patient must be advised on a liquid diet and strict oral hygiene. In the case described, splinting was performed by extending two teeth beyond the fracture line, providing stability to the fractured segment. This one lasted for forty-five days, and the patient was kept on a liquid diet during this period.

Although the literature recommends immediate treatment, in this case, the therapy was established 04 days after the trauma, when the individual attended the urgency and emergency unit. A late conservative intervention was performed, and despite this, long-term success was obtained, confirmed by clinical-radiographic control.

The pulp condition should only be evaluated from the 4th week after the trauma, with the aid of sensitivity tests (electrical or thermal), since, when performed early, they can designate a nonconclusive result due to acute trauma in the region (CHAUHAN, 2016; BOURGUIGNON et al., 2020). The patient, in this case, underwent an endodontic evaluation in the third week after the trauma, with clinical and imaging follow-up for six months.

Complications such as pulp necrosis, infection, canal obliteration, root resorption, and collapse of the marginal gingiva and bone are reported in the literature. The detection of these complications must be performed early so that the prognosis is favorable (BOURGUIGNON et al., 2020). In the case discussed, units 11 and 12 had previous endodontic treatment, unit 21 evolved with pulp necrosis and internal root resorption, and unit 22 with pulp necrosis, requiring endodontic intervention in both.

\section{CONCLUSION}

Dentists must know how to diagnose, manage and treat patients who are victims of dentoalveolar trauma, as decision-making in the first hours after trauma is crucial and determinant for the success of the treatment. Despite this, the late intervention of alveolar fractures through closed reduction and installation of semi-rigid containment demonstrates effectiveness in stabilizing the segment and providing a favorable environment for adequate bone healing, with the success of this treatment evidenced in the case reported. 


\section{REFERENCES}

ALIMOHAMMADI, R. Imaging of dentoalveolar and jaw trauma. Radiologic Clinics of North America, v. 56, n. 1, p. 105-124, 2018.

BOURGUIGNON, C. et al. International Association of Dental Traumatology guidelines for the management of traumatic dental injuries: 1. Fractures and luxations. Dental Traumatoly, v. 36, n. 4, p. 314-330, 2020.

CHAUHAN, R. et al. Adult dental trauma: What should the dental practitioner know? Primary Dental Journal, v. 5, n. 2, p. 66-77, 2016.

DEANGELIS, A. F. et al. Review article: Maxillofacial emergencies: Dentoalveolar and temporomandibular joint trauma. Emergency Medicine Australasia, v. 26, n. 5, p. 439-445, 2014.

FONSECA, R. J. et al. Trauma Bucomaxilofacial. 4. ed. Rio de Janeiro: Editora Elsevier, 2015.

HAMMEL, J. M.; FISCHEL, J. Dental emergencies. Emergency Medicine Clinics of North America, v. 37, n. 1, p. 81-93, 2019.

HUPP, J. R.; TUCKER, M. R.; ELLIS, E. Cirurgia oral e maxilofacial contemporânea. 6. ed. Rio de Janeiro: Editora Elsevier, 2015. 692 p.

KALLEL, I. et al. The incidence of complications of dental trauma and associated factors: A retrospective study. International Journal of Dentistry, v. 2020, p. 1-8, 2020.

MILORO, M. et al., Princípios de cirurgia bucomaxilofacial de Peterson. 3. ed. São Paulo: Santos Editora, 2016.

PATIL, V. H.; ANEGUNDI, R. Management of dentoalveolar trauma - 11/2 year follow up: A case report. Indian Journal of Dental Advancements, v. 8, n. 3, p. 187-189, 2016.

ZAMBONI, R. A. et al. Levantamento epidemiológico das fraturas de face do Serviço de Cirurgia e Traumatologia Bucomaxilofacial da Santa Casa de Misericórdia de Porto Alegre - RS. Revista do Colégio Brasileiro de Cirurgiões, v. 44, n. 5, p. 491-497, 2017. 